\title{
ChILDREN AND GENOCIDE
}

\section{PANAYIOTIS DiAMADIS}

This essay examines the evolution, since antiquity, of the forcible transfer of children by dominant groups at the expense of subordinate groups. It traces the development of the intentions, motivations and justifications behind this practice. Deliberate, systematic mass abduction and forced assimilation have enabled the exploitation of children as working slaves, as sexual chattels, as deft or supple skilled workers, and as 'substitute' progeny. This study highlights aspects of the phenomenon across societies and generations. It is designed to provide a broad background to the defining of the forcible transfer of children as an act of genocide, an act deemed criminal in international law since 1948.

The United Nations Convention on the Punishment and Prevention of the Crime of Genocide 1 identifies five acts that can constitute the crime, any one of which when conducted 'with intent to destroy, in whole or in part, a national, ethnical, racial or religious group', constitutes genocide. The first four acts $^{2}$ are linked by the common element of the physical extermination of, or physical harm to, human life. Article II(e) stands out because while it still involves a systematic attack on the group's essential foundations, it does not involve the actual extinction or attempted destruction of biological life.

1 Adopted by the General Assembly by Resolution 260 (III) on 9 December 1948.

2 Article II(a) - 'killing'; (b) 'causing bodily or mental harm'; (c) 'deliberately inflicting on the [victim] group conditions of life calculated to bring about its physical destruction'; (d) 'imposing measures intended to prevent births' - have the common element of involving the physical destruction of human life. 
How then does the forcible transfer of children ${ }^{3}$ achieve a perpetrator's aim of destroying a targeted group? Where did the drafters of the Genocide Convention (including the Polish jurist Raphael Lemkin) find cause to include this behaviour as a criminal act in the legal definition of genocide? An examination of a series of case studies across history may provide some answers.

While child removal by governmental entities has taken place since antiquity, it is only in the last century that these acts have been deemed genocidal. Specific cases show that a defining element has been the intent of the perpetrators to destroy their chosen victim groups - in whole or in partthrough the removal of their young and 'processing' them into a new culture or belief system. This was usually, but not always, carried out in addition to the more typical methods employed in the physical destruction of targeted groups. Nazi Germany, for example, removed and 'Germanised' some 200,000 Polish, Russian, Ukrainian and other European children, but systematically murdered 1.1 million Jewish children.

\section{Enslavement and voluntary assimilation}

The employment of means of killing en masse as 'solutions' to

${ }^{3}$ As the definition of childhood differs between societies and cultures, for the purposes of this essay the phrases 'children and teenagers', 'the young' or 'youth' are used for persons below the age of adulthood. During the Armenian Genocide, for example, the United States Consul in Trapezounta (Trebizond/modern Trabzon), Oscar S Heizer, made the following note in one of his reports: 'Girls up to 15 years of age inclusive, and boys to 10 years of age inclusive are accepted; those over these ages are compelled to go with their parents', Report to US Ambassador to Constantinople Henry Morgenthau, 7 July 1915. The Ottoman Turkish authorities employed these ages to identify 'children', whereas most Western societies define the individual's 18th birthday as marking the age of maturity, regardless of gender. 
social, political and economic problems have been recorded since earliest history. Thus, The Iliad by Homer, the Old Testament, and the archives of the Assyrian and NeoBabylonian Empires contain the earliest accounts of targeted mass murder. These events also typically involved the wholesale transfer of captive children and teenagers for use as manual, skilled, domestic, and sexual slaves.

These situations differ from their later counterparts in the nature of the perpetrators' intent. The victors did not enslave tens of thousands of children and youth to destroy their opponents as distinct groups. Their defeat on the field of battle and subsequent destruction of their military capabilities were the aims of the victorious kings and generals who ordered the forced transfers of the underage persons. Forcible transfer of the young was most often a byproduct of the subjugation of the vanquished.

The rise of Islam and the Arab Empire from the mid-600s CE brought a major shift in attitude towards the enslavement of humans and transfer of youth. The Prophet Mohammed forbade free-born Muslims being made slaves. ${ }^{4}$ Yet the economic requirements of the Caliphate demanded the continuation of the slave trade. The dilemma was resolved by sourcing slaves from among the non-Muslim peoples of subSaharan Africa and Europe. These new slaves were, in time, converted to Mohammed's faith, ensuring that these children would be able to live their lives as free and equal citizens. Thus victim group children were actively and passively encouraged to abandon their original identities and assimilate into the dominant group. The practice became state policy

${ }^{4}$ Lofkrantz, Jennifer (2011), 'Protecting freeborn Muslims: The Sokoto Caliphate's attempts to prevent enslavement and its acceptance of the strategy of ransoming', Slavery and Abolition, vol 32, February, 109-27. 
and resulted in a substantial increase in the numbers of the dominant group at the expense of the subjugated.

Over centuries, the subject groups would cease to exist as they could no longer reproduce themselves and sustain their ethnicity and culture. An illustrative example is the indigenous Assyrian population of Mesopotamia (modern southeast Turkey and northern Iraq). In the period of 13 centuries since the Islamic conquest of their homeland, the Assyrians have changed from being the largest group in their homeland to a minority so small it is clinging to its very existence.

Lemkin and his Genocide Convention drafting colleagues had these practices in mind when they included the act of forcible transfer of children in their genocide definition. In the opening paragraph of the chapter on 'Genocide' in his 1944 work, Axis Rule in Occupied Europe, Lemkin states that the term genocide 'is intended rather to signify a co-ordinated plan of different actions aiming at the destruction of the essential foundations of life of national groups, with the aim of annihilating the groups themselves'.5 Albeit a long-term method, child removal was seen as a serious contribution to the eventual annihilation or decimation of a group.

\section{Devshirme}

The Islamic Arab Empire's system of recruiting administrators and fighters from amongst non-Muslim slaves and prisoners of war was adapted by the Ottoman Turkish Empire. Founded in 1299 by Sultan Uthman I, ${ }^{6}$ it was under his successor, Orkhan, ${ }^{7}$ that a revolutionary tax was

${ }^{5}$ Lemkin, Raphael (1944), Axis Rule in Europe: Laws of occupation, analysis of government, proposals for redress, Washington DC, Carnegie Endowment for International Peace, 80.

${ }^{6}$ Reigned 1299-1326.

7 Reigned 1326-1359. 
introduced, the devshirme. ${ }^{8}$ Payment was made in the form of children, collected from the empire's Christian subjects alone.

Under Sultan Murad II, ${ }^{9}$ the devshirme became regulated. Ottoman soldiers and army doctors would tour rural areas of the Empire to draft recruits from among children aged six to 16. According to historian Artak Shakaryan, this range was so wide because the physical appearance of the child was more important than his or her actual age. 'A devshirme child had to be healthy, not too tall or too short and not too fat or too thin.' ${ }^{\prime 10}$ Children who were collected and brought to Constantinople (today's Istanbul) would be shown to devshirme specialists. Based primarily on their physical characteristics, but also on verbal tests, these 'experts' would suggest in which realm the removed children would be suitable. The most attractive and intelligent were sent to the palace; others were absorbed by Jannisary Corps (military musketeer units); the rest were sold as slaves. Available sources allow us to approximate that 60 per cent of the children would be enslaved, 30 percent would become Janissaries, and only 10 percent would go to the palace. Until the mid-1600s, those who went to the court of the Sultan dominated the imperial government. They were totally reliant on the Sultan for their wealth and power, but their sons, as free-born Muslims, could not inherit their positions. ${ }^{11}$

As Bat Ye'or wrote in The Decline of Eastern Christianity

8 It may be loosely translated as 'child-gathering'.

${ }^{9}$ Reigned 1421-1451.

10 Suciyan, Talin (2007), 'Study sheds light on Ottoman Blood Tax' (interview with Artak Shakaryan), Armenian Reporter, 2 June, http://www.armenianreporteronline.com/generating/pdf/jun022007/A0602.pdf

${ }^{11}$ Ibid. 
under Islam, the offspring of 'dhimmis'12 were regarded as a reservoir of slaves for economic or political purposes. In 1836, for example, Sultan Mahmud II (Adli) ordered the dispatch of Armenian children and teenagers aged eight to 15 years from Sevasteia (modern Sivas) and other Anatolian towns to the imperial capital where they were put to work at the spinning mill, royal shipyard, to manufacture ship sails and produce iron in the foundries. Payment consisted of bread and clothing. Avedis Perperean, writing in 1871, recorded that:

this order is renewed year after year and they collect hundreds of Armenian children from every town, depriving them of their parents and their homeland, and during this thirty-day march in bare feet and rags, take them to Constantinople. Several die of cold and want on the way and later through the tyranny of their masters, while others convert to Islam, hoping thus to obtain their freedom. ${ }^{13}$

The devshirme met the need for personnel in the empire-at the expense of their Christian subjects. Generations of future leaders and potential opponents were systematically removed by the Ottoman state. The devshirme served different needs of the rising imperial power. First, it gave the Ottoman Turks a legitimate solution to their 'problem' of how to deal with thousands of prisoners of war captured from various Christian rival states. Second, it provided the (until recently) nomadic Turkic tribes with the knowledge of administration required to maintain an empire. Third, and arguably the most important asset, it provided the Ottoman Turkish state with a means of population control.

When the Turkic tribes first invaded Anatolia in 1061, they were a small, powerful, warrior elite. They had subjected a large non-Muslim population through force of arms while still

12 Non-Muslim monotheistic subjects of Islamic states.

${ }^{13}$ Ye' or, Bat (1996), The Decline of Eastern Christianity under Islam, New York, Associated University Presses, 113. 
a small minority. The system of the devshirme permitted the new rulers to methodically enfeeble their non-Muslim subject populations by forcibly removing a portion of their children at regular intervals. Over the lifetime of the Ottoman Empire (almost six centuries), the devshirme played a major role in reversing the demographic face of Anatolia. During this period, the territory went from being almost exclusively Christian in population in the 1000s, to having an Islamic majority by the 1800s. While the intent of the Ottoman Court may not have been intentionally genocidal in the Convention's sense, the effect of policies and practices such as the devshirme was definitely genocidal.

\section{Colonial contexts}

Just as their European rivals did, from the mid-1000s the Seljuk and Ottoman Sultans dominated peoples and lands other than their own. The Turkish Sultans looked to their Islamic religion for explanation and justification of how they came to dominate the Near East. In a similar way, the European colonisers looked initially to religion for explanations of their world views. The Renaissance and the subsequent Scientific Revolution meant that theological justification did not satisfy as it once did. Science was looked to as a means of providing more rational analyses. One result of this fusion of theology and science was the movement that came to be known as 'scientific racism' - which may be defined as 'the attempt to develop biological solutions for social problems', typically building upon theological foundations. According to Robert Proctor, it 'was an explanatory program, but it was also a political program, designed to reinforce certain power relations as natural and inevitable'. ${ }^{14}$ In the words of social philosopher David Hume

14 Proctor, Robert (1998), Racial Hygiene: Medicine under the Nazis, Cambridge, Harvard University Press, 13. 
(regarded as the father of the social sciences):

I am apt to suspect the Negroes to be naturally inferior to the Whites. There scarcely ever was a civilised nation of that complexion, nor even any individual, eminent either in action or in speculation. No ingenious manufacture among them, no arts, no sciences. 15

The emergence of this school of thought from the $1800 \mathrm{~s}$ rapidly brought an impact on the indigenous peoples of a number of territories colonised by European powers and by the British Empire in particular. Unlike their continental European rivals, which preferred to maintain social and familial barriers between conquerors and conquered, the British instituted the assimilation of the indigenous peoples of a number of the territories they colonised-Australia, New Zealand, Canada, the United States as the most prominent examples.

An outcome of the social revolution brought about by the explosion of scientific knowledge of the 1800s was the incorporation of the 'racial' element to existing religious prejudices. This 'scientific racism' was particularly applied to indigenous peoples in British colonies and dominions as highlighted by the forcible transfer and accompanying assimilation of indigenous youth. 'Scientific' justification was provided by academics, theological justification from clergymen, and bureaucratic 'social' justification for the abduction of children and teenagers from hearth and home, ostensibly 'for their own good'.

Western eugenicists in the early 1900s were aware of the Janissary phenomenon. As recorded by Henry Morgenthau, converts, voluntary and forced,

strengthen the Empire as the Janissaries had strengthened it

${ }^{15}$ Hume, David (1826/2004), The Philosophical Works of David Hume, Boston, Adamant Media Corporation. 
formerly. These Armenian girls represent a high type of womanhood and the Young Turks, in their crude, intuitive way, recognised that the mingling of their blood with the Turkish population would exert a eugenic influence upon the whole. 16

A similar principle was at work in colonial Canada, America, Australia and New Zealand-not so much for the improvement of the British 'bloodline' by absorbing the indigenous peoples but as a way of eliminating a threat to the colonists' designs for their new lands. In these plans, nonEuropeans were assigned subservient roles, if they were permitted to retain a distinct identity at all.

The Canadian residential school system, for example, consisted of a number of institutions for indigenous children, operated since the $1800 \mathrm{~s}$ by churches of various denominations (about 60 per cent Roman Catholic, and 30 per cent Protestant). They were funded under the Indian Act by Indian and Northern Affairs Canada, a branch of the federal government. The schools' purpose was 'to take the Indian out of the Queen's Red Children' according to the Gradual Civilization Act (1857) under which the system was implemented. ${ }^{17}$ Students were often forcibly removed from their homes, parents, and communities. Most had no contact with their families for up to ten months at a time because of the distance from home. Often, they did not have contact with their families for years at a time. The locations of the schools were planned deliberately to ensure a 'proper distance' from the reserves. They were required to stay in residences on school premises, often walled or fortified in some manner.

${ }^{16}$ Morgenthau, Henry (2004), Ambassador Morgenthau's Story, Whitefish, Montana, Kessinger Publishing, 182.

17 'Ottawa, United Church must pay for abuse', The Globe and Mail, 21 October 2005. 
Students were prohibited from speaking indigenous languages, so that English or French would be successfully learned and their own languages forgotten. They were subject to often unreasonably severe corporal punishment for speaking other languages or practising non-Christian faiths. The process of phasing out these institutions began in the 1970s and the last one did not close its doors until 1996.18

Australia's practice of forcible child removal was assuredly the most thorough in the colonial context. Europeans had been visiting various parts of the Australian coast from the 1600s. The invasion and colonisation of the continent was undertaken by the British from 1788. Europeans rapidly spread out from the harbour now known as Sydney, colonising the country within 14 decades. The fierce resistance of the indigenous people was no match for the technological superiority of the European colonists. By 1860, the Parliament of the Colony of South Australia had been presented with a report declaring that the country's indigenous inhabitants were doomed to extinction. ${ }^{19}$ A few years later (1873), the English writer Anthony Trollope wrote that the 'doom' of the Australian Aborigines 'is to be exterminated, fragments of them only remain' ${ }^{20}$

In The Australian Race, E M Carr stated that 'the White race seems destined, not to absorb, but to exterminate the Blacks of

18 See Wertz, Jay (2008), The Native American Experience, London, Andre Deutsch, 42.

19 The Report of the Select Committee of the Legislative Council upon the Aborigines Together with Minutes of Evidence and Appendix, South Australian Parliamentary Papers, 1860, vol 3, no 165, as cited in Kimber, Richard (1997), 'Genocide or Not? The Situation in Central Australia' in Genocide Perspectives I, Colin Tatz (ed), Sydney, Centre for Comparative Genocide Studies, 34.

20 Tatz, Colin (1997), 'Genocide and the Politics of Memory', Genocide Perspectives I, Sydney, Centre for Comparative Genocide Studies, 315. 
Australia'. ${ }^{21}$ The question of the dominant Europeans 'absorbing' the minority indigenous population largely grew out of the emergence of a new 'mixed race' population in Australia. Since the earliest days of British colonisation, European men had been taking Aboriginal women as sexual partners. As late as the 1890s, evidence was being presented to colonial parliamentary inquiries that the abduction and rape of Aboriginal women was common. ${ }^{22}$ The result of these (typically involuntary) unions was the population of 'mixed race' children. 'Full-blood' indigenous Australians were deemed to be a 'dying race' and therefore of little consequence; these 'mixed race' youngsters were deemed to be a threat to the dream of an Australia that was 'white' and British.

Morgan Blum states that the solution hit upon for this 'Aboriginal problem' in newly-independent Australia was through biological absorption. ${ }^{23}$ In brief, Aboriginal children were to be removed from their families, educated in state and private institutions as livestock and agricultural labourers or domestic servants, and severed from all contact with their native people and culture. Such removals, or 'retentions' of Aboriginal children, began as systematic policy in colony Victoria as early as 1839. The Colonial Secretary of New South Wales stated during a debate in that state's parliament on the

${ }^{21}$ Carr, E M (1886), The Australian Race, Melbourne, Government Printer, vol 1, 100-06, cited in Kimber, 41.

22 Willshire, W H (1896), The Land of the Dawning, and evidence presented to the Select Committee on the Aborigines Bill (1897) in Reynolds, Henry (1972), Aborigines and Settlers: The Australian experience, Melbourne, Cassell Australia, 28-32.

23 Blum, Morgan (2006), 'Forced child removal in Western Australia' in Tatz, C and S (eds) (2006), Genocide Perspectives III, Sydney, Australian Institute for Holocaust and Genocide Studies, 115-39. 
Aborigines Protection Amendment Bill on 27 January 1915:

The Aboriginals will soon become a negligible quantity and the young people will merge into the present civilisation and become worthy citizens... It is not a question of stealing the children but saving them. The moral status of these Aboriginals is very different from that of white people. ${ }^{24}$

Although Social Darwinist ideology held that the Aboriginal 'race' would sooner or later die out, it was decided that the process was to be hastened by 'breeding them out'. From 1839, the colony of Victoria began removing Aboriginal children from their families. In 1909, C F Gale, Chief Protector of Aborigines in the state of Western Australia, reported the view of one of his inspectors on taking children from their mothers: 'no matter how frantic her momentary grief might be at this time, they soon forget their offspring' . ${ }^{25}$ Years later, in 1937, a federal-state government conference on Native Welfare adopted a resolution that stated, in part, that 'the destiny of the natives of aboriginal origin, but not of the full blood, lies in their ultimate absorption by the people of the Commonwealth, and it therefore recommends that all efforts be directed to that end.'26

Those removed have come to be called the Stolen Generations, a term coined by historian Peter Read in 1981.

24 The Hansard was cited by Premier of New South Wales, R J Carr, during his address on 'Stolen Aboriginal Children', 18 June 1997, http://www.parliament.nsw.gov.au/prod/parlment/hansart.nsf/V 3Key/LA19970618005

${ }^{25}$ Report of the Chief Protector of Aborigines (1909), West Australian Parliament Votes and Proceedings, vol 2, 2 as cited in Tatz, Colin (1997), 'Genocide and the Politics of Memory' in Genocide Perspectives I, Sydney, Centre for Comparative Genocide Studies, 315.

${ }^{26}$ Human Rights and Equal Opportunity Commission Australia - A national overview, December 2007, http://www.hreoc.gov.au/education/bth/download/history/bth_ note_taking_3r.pdf 
Political scientist Robert Manne suggests that 'approximately 20,000 to 25,000' were removed between 1910 and 1970, based on the Australian Bureau of Statistics report of 1994. ${ }^{27}$ The figure may be substantially higher as the report noted that formal records of removals were very poorly kept, and many records 'went missing' when inquiries began. Although very few children of full Aboriginal descent were removed, 'halfcastes' - the children of 'mixed descent' - were the most targeted. Estimates were given that between 10 and 30 per cent of all Aboriginal children born during the period were removed by state and federal authorities.

As young men formally educated in the early 1900s, Lemkin and his colleagues would have been exposed to eugenicist teachings during their secondary and tertiary educations. Such Social Darwinism as practised in Australia was the predominant ideology in the Western world. Therefore, the forcible transfers of indigenous children and teenagers in Oceania and North America into state-run institutions during the lifetimes of Lemkin and his colleagues provided them with an immediacy of experience. That was significant to their later work on codifying genocide and the relationship of children to this crime.

\section{The Hellenic, Armenian and Assyrian genocides}

Samantha Power, writing in 'A Problem from Hell': America and the age of genocide, highlights the impact that knowledge of the Armenian Genocide had on Lemkin from his student days at the University of Lvov (modern Lvyv, Ukraine). ${ }^{28}$ In his

27 Manne, Robert (2010), 'Comment: Keith Windschuttle', The Monthly http:/ / www.themonthly.com.au/nation-reviewed-robertmanne-comment-keith-windschuttle-2256 accessed 13 May 2012. 28 Power, Samantha (2003), 'A Problem from Hell': America and the age of genocide, London, Flamingo, 17-20. 
unpublished essay, 'Nature of Genocide', Lemkin compared the treatment of the Moris $\cos ^{29}$ with the deportation marches of the Armenians. His conclusion was that 'techniques of physical genocide have repeated themselves through history' ${ }^{30}$ Attacks on the family unit constitute biological methods of genocide. Lemkin specifically cited the Ottoman Turkish Empire as another recurring theme in the history of genocide: 'The children can be taken away from a given group for the purpose of educating them within the framework of another human group, racial, religious, national or ethnical' ${ }^{31}$

Robert Kempner, responsible for preparing the cases against the leading Nazis at Nuremberg, had earlier written a legal paper on the Armenian genocide. ${ }^{32}$ The forcible transfer of Christian Hellene, Armenian and Assyrian children by the Ottoman state, its auxiliaries and successors was 'an integral part of the Hellenic, Armenian and Assyrian genocides (19141924) and a key historical precedent to the inclusion of the forcible transfer of children as an act of genocide.'

Amid the (till then) unprecedented civilian death toll of the triple genocide that wracked Anatolia for a decade, the forcible transfer of tens of thousands of children and teenagers is an oft overlooked aspect of the deliberate destruction of the indigenous peoples of Anatolia. ${ }^{33}$ Taner

29 See The Revolt of the Moriscos

http://www.historylearningsite.co.uk/moriscos.htm

30 Docker, John (2008), The Origins of Violence: Religion, history and genocide, North Melbourne, Pluto Press, 12.

${ }^{31} \mathrm{Ibid}, 13$.

32 Hosfield, Rolf (2005), 'The Armenian Massacre and Its Avengers. The ramifications of the assassination of Talaat Pasha in Berlin', Internationale Politik, vol 6, Fall.

33 Bjornlund, Matthias (2009),'A fate worse than dying': sexual violence during the Armenian Genocide' in Herzog, Dagmar (ed), Brutality and Desire: War and sexuality in Europe's twentieth century, 
Akçam and others have recognised that the pre-World War I pogrom against the Hellenes in eastern Thrace and western Anatolia constituted a dress rehearsal for the Armenian Genocide. The Danish Consul in Smyrne (modern Izmir) reported in March 1914 that the provincial valis (governorsgeneral) had conducted tours of inspection of coastal settlements. They advised the local Muslim leaders to force the Hellenic population out, first by economic boycotts; and when that did not have the desired effect, by violent persecution. ${ }^{34}$

The favoured method of killing came to be known as the 'white death' by the Hellene deportees. It was so named because it did not involve the shedding of blood. The victims were simply marched across Anatolia, without provisions, until they dropped by the wayside of hunger, dehydration, infection, disease or exposure. Many of those who made it to the final destination-the desert of northern Syria-were butchered. ${ }^{35}$ En route, thousands of women and children were forcibly removed from the caravans of death by the Ottoman guards, by Kurdish tribesmen or by Bedouin nomads. As recorded by League of Nations reports, 'young women and girls were kept for the harems; with few exceptions, they

London, Palgrave Macmillan, 35.

34 Bjornlund, Matthias, cited above (footnote 33), 31.

35 Danish missionary Karen Jeppe, described one scene she came across on her travels around Anatolia during the genocides:

'Starving Armenian women and children throwing themselves on the body of a dead donkey, tearing it to pieces and devouring it; Turkish children worrying [harassing] little Armenians till they died in the road; exhausted people falling on all fours and crawling along - still driven - till they also died among the other dead people who strewed the roads; and at last a long train of women and girls naked driven on and on', Manchester Guardian, 8 October 1926. 
were violated as soon as captured' ${ }^{36}$ Cities like Harput and Mezreh became centres of the trade in Armenian, Hellene and Assyrian slaves,

where the most desirable females, first and foremost women of wealthy families, were searched for by local Muslims and checked by doctors for diseases etc. If a woman refused to follow her new 'owner', she was detained by the local authorities until she accepted a life in slavery. ${ }^{37}$

The Christian captives were forcibly Islamised, renamed and assimilated into the households of their captors, either as wives or servants. As time went on, the native Armenian, Hellenic or Assyrian tongues of these victims came to be forgotten. Although the older ones retained some memory of their lives before the genocide, the younger ones came to forget that they were ever Christian. ${ }^{38}$

One of the first individuals to attempt a rescue effort was Karen Jeppe. While she was able to affect a few individuals during the War years, the sheer scale of the problem was overwhelming. Not until the conclusion of the war and the occupation of large parts of the Ottoman Empire by the Allied powers were large numbers of Armenian, Hellene and Assyrian women released from captivity. ${ }^{39}$

36 Records of 8th Assembly, Minutes of 5th Committee, $51 \mathrm{ff}$.

37 Bjornlund, 23.

38 In keeping with local tribal customs, and in order to discourage escape attempts, the perpetrators would often brand their captives with tattoos on their faces or necks. When incised into the skins of Anatolian Christian women, these markings represented a new communal as well as personal belonging.

${ }^{39}$ According to a League of Nations report titled 'The Rescue of Deported Women and Children', in 1921 no less than 90,819 Armenian orphans had been reclaimed from Turkey, Syria, Cyprus, Egypt, Armenia and Georgia. Macartney, C A (1930), Refugees: The work of the League, League of Nations Union, London, 
Elif Shafak's novel, The Bastard of Istanbul,40 deals with the complexity of the consequences of the forcible removal and subsequent forced Islamisation, of Christian children by Muslim soldiers and irregulars, three generations after the initial events. The novel's key episode unfolds in this way:

.... horde of bandits arrived, searching and plundering the houses. They stopped and ransacked every Turkish and Kurdish village in the region. It didn't take them long to find out that there was a little Armenian girl there... They had heard about the orders to deliver all Armenian orphans below the age of twelve to the orphanages around the country... Like all of the children there she was dressed in a white robe and a buttonless, black coat. There were both boys and girls. The boys were circumcised and all the children were renamed. So was Shushan. Everyone called her Shermin now. She was also given a surname: $626 .{ }^{41}$

While The Bastard of Istanbul is fiction, there are substantial threads of fact running through it. This extract refers, in effect, to a renewal of the devshirme. The orphanage Shushan was removed to remains nameless in the novel. One of these centres was at Aintoura in Ottoman Syria. ${ }^{42}$ The school became home to 800 orphans, 30 soldiers who guarded the compound and a staff of 10 Lebanese. The boys were circumcised and given Islamic names beginning with the first letter of their Armenian names: Haroutiun Najarian became Hamid Nazim, Boghos Merdanian became Bekim Mohammed, Sarkis Sarafian became Safwad Suleyman.

Pelican Press.

40 Shafak, Elif (2008), The Bastard of Istanbul, London, Penguin.

${ }^{41}$ Ibid, 242.

42 The former French school at Aintoura is near Zouk, in the Keserwan district of Lebanon, about a half hour drive north of Beirut. 
Partly due to director Nebih Bey's incompetence, poor sanitary conditions, disease and malnutrition prevailed, many children died, attracting the attention of the central government. Aintoura was visited by Cemal Pasha, ${ }^{43}$ who upon arrival dismissed Nebih and appointed Halide Hanum ${ }^{44}$ as principal of the orphanage. This aspect of the Aintoura story was recorded in a photograph caption in The Lions of Marash. ${ }^{45}$ Cemal also brought 400 new orphans between the ages of three and 15 years. They were accompanied by 15 young women from powerful Turkish families, part of the 40strong team whose task was to Islamise and Turkify the Christian Armenian orphans. While Lebanon was wracked by famine, livestock and grain were available at Aintoura in abundance. Education was only in Turkish. The older orphans were taught various trades, like shoemaking and carpentry. The mullah called the children to prayer five times a day. Every night the school band would play 'Long live Cemal Pasha'.

${ }^{43}$ Commander of the Syrian-based Fourth Turkish Army, and the junior member of the triumvirate that ruled the Ottoman Empire between 1913 and 1918. From Pasha, Cemal (1922), Memoirs of a Turkish Statesman 1913-1919, New York, George H Doran Company, http://archive.org/details/memoriesofturkis00cemarich ${ }^{44}$ Halide Edib Hanum (later known as Halide Edib Adivar, 18841964) was a famous Turkish feminist, author and nationalist. She was assisted by five Lebanese nuns from the Sacred Heart Order, who were made responsible for sanitation and nutrition. Besides Aintoura, Halide Hanum was also responsible for the Sisters of Nazareth school in Beirut, until its closure in 1917. Halide had the final say on everything, aiming to develop the ideal Turkish nationalist educational institution, a model for the new Turkey that was to come after the successful conclusion of the war. 45 The Lions of Marash was written by Stanley E Kerr, President of the American University of Beirut. In this volume, Kerr recorded his personal experiences working with the Near East Relief organisation between 1919 and 1922. 
The Ottoman Army abandoned Lebanon in early 1918, with French forces moving in. The orphanage at Aintoura was in chaos, the 470 boys and 200 girls abandoned. The Catholic clerics approached Bayard Dodge, an officer of the American University of Beirut, for assistance; shipments of food began to arrive through the American Red Cross. With order restored, the process of reversing the Turkification process began, by encouraging the use of the orphans' Armenian names. ${ }^{46}$

Largely through the efforts of the relief workers throughout the Ottoman Empire, the events unfolding were made known across the world almost immediately. For example, the story of one of the abducted children, Aurora Mardiganian, was made into a film in 1918, Ravished Armenia. Under the title Auction of Souls, it was screened throughout the British Empire, with The Herald newspaper in Melbourne advertising screenings in February 1920.47

The primary source of evidence on the involvement of the Turkish state in the forcible transfer of Christian young into

46 The American Red Cross appointed Mr Crawford as principal, brought in Armenian teachers who delivered education in Armenian and English. In its final months, the Near East Relief organisation took over. In autumn 1919, the male orphans were sent to Aleppo, Syria, and the females to the Armenian orphanage in the village of Ghazir, Lebanon. In 1993, the school directors decided to build an extension in the rear of the complex. When the ground was disturbed, the workers came across human remains. These bones were all that remained of the estimated 300 Armenian orphans who died during the time Aintoura was run by the Ottoman state. The remains were gathered and given a Christian burial in the cemetery belonging to the Aintoura priests. Aztag, Armenian Daily, Lebanon, February 2006.

${ }^{47}$ Auction of Souls (advertisement), The Herald, Melbourne, 25 February 1920. 
Muslim households comes from the Extraordinary Courts Martial, instituted by the new Turkish Government in March 1919 to try officials from the Ittihad ve Terakke $i$ Cemayeti. A Turkish commentator, writing in a Turkish-language newspaper in Constantinople the following month, described these as 'the most important trial[s] in the six hundred year history of the Ottoman Empire'. ${ }^{48}$ The trials, held in major centres across Anatolia in 1919 and 1920, were recorded in the official Ottoman government gazette, Takvim-i Vekayi. The Courts Martial recorded that the systematic distribution and abuse of Armenian females and boys was practised at the highest levels of Turkish society. For example, the chief police officer of Trapezounta (Trebizond/modern Trabzon), a man named Nuri, brought young Christian girls to Constantinople as gifts from the Governor-General to members of the Ittihad's central Committee.

With knowledge of these events spread by the international media and by charitable organisations such as Near East Relief, it is fairly certain that Lemkin and his colleagues would have been moved by this exposure to include the forcible transfer of children in the United Nations' Convention a mere two decades later.

\section{The Republican phase 1919-1924}

These child removals were by no means limited to the Ottoman period. The practice continued with barely a pause as Kemal's Republican forces assumed control across Anatolia. A specific clause was inserted in the peace Treaty of Sevres (1920), binding the Turkish authorities 'to allow and give all assistance to a League of Nations Commission to make enquiries and liberate the remaining victims'. Mustafa Kemal's revolution against the Ottoman Sultan prevented ratification and implementation of the treaty's provisions.

48 Tatz, Colin (1997), Genocide Perspectives I, Sydney, Centre for Comparative Genocide Studies, Macquarie University, 321. 
Relief workers in the Middle East estimated that by 1921 there remained an estimated 12,000 captive Christian women and children (predominantly Armenian) even in the areas occupied by the Allies (mainly among the Arabs of Syria). In addition, there were some 70,000 captives amongst the Muslim inhabitants in the interior of Anatolia, in areas beyond the reach of the Allied forces and of western relief workers. In 1922, Jeppe-by now a League of Nations Commissary-reported that there were approximately 6,000 Christian women and children held in Muslim households in the French zone ${ }^{49}$, and at least 30,000 in the district accessible from Aleppo, including some hundreds in Aleppo itself. The French refused permission to send a rescue mission among the Arab tribes 'on the ground that this would only produce a fresh outburst of anti-foreign fanaticism', and even in Aleppo the women could not be rescued for fear of disturbances. ${ }^{50}$

These abductions of Christian children were not restricted to females. Vasileios Anastasiades was born in the Kaesareia (Kayseri) district of Kappadokia but grew up in the town of Ak Dagh Maden, Pontos. His family was deported in 1916. After World War I, Anastasiades was reunited with the surviving members of his family, only to be exiled again in 1920 'when the Turks hit Pelemet, attacking the French'. The men were separated from the women. The children were assembled as a separate group and sent to Zonguldagh on the Black Sea coast of north-west Anatolia:

Next to us was a camp for Hellene prisoners of war, all but one of whom died as slave labourers. The sole survivor was Demetrios Pairahtaroglou. The soldiers gave us some of their

${ }^{49}$ The Cilicia region of modern Turkey, as well as modern Syria and Lebanon.

50 See Macartney, C A (1930), Refugees: The work of the League, League of Nations Union, London, Pelican Press. 
meagre food rations, so that we would not starve to death. When the Red Cross was notified about us and came looking for us, the Turks would move us around by night. One Christian prisoner, who was serving as a guard, told the Red Cross where we were hidden, on condition that they free him also. That is how 150 children were saved. I came to Hellas in $1924 .{ }^{51}$

Despoina Ioannou's story illustrates the use of forcibly removed Christian children and teenagers as slave labour during Kemal's time in power. Ioannou was born in Palaia Phokaia (modern Eski Foca), a small city north of Smyrne on Anatolia's Aegean coast. In September 1922, she was deported on foot, first to Kediz, then to Menemene. There, the male deportees were separated from the females. Ioannou escaped, only to be recaptured and returned to Phokaia. After convincing the Turkish authorities that she was someone else, Ioannou was sent on another march, this time to Ankara. There she was assigned to serve a French family as a domestic servant. Ioannou revealed her true identity when a letter arrived seeking news of her whereabouts. With the help of the French family she served, Ioannou was reunited with the surviving members of her family in Piraeus. ${ }^{52}$

\section{Reverberations}

Within a decade, the physical indigenous Christian presence had been virtually extinguished. By 1925, what remained was-on the surface at least-a 'purely' Turkish Muslim population. In recent years, this image has begun to metamorphose. The exploration of their own genealogies is leading large numbers of people in Turkey to 'discover' Armenians and/or Hellenes and/or Assyrians in their own

${ }^{51}$ Anastasiades, Vasileios. Extract translated by Panayiotis Diamadis.

52 Horbos, Nikolaos (1988), Palaia Phokaia-Mikras Asias [Old Phokaia - Asia Minor] Thessalonike: Ekdoseis Gramma, 215-16.

Extract translated by Panayiotis Diamadis. 
immediate ancestry. The rediscovery of this cultural diversity in Anatolia is also making itself felt through the literature produced by authors who identify themselves as Turkish. Writers like Elif Shafak and Fethiye Çetin are a prime illustration.

Representative of the more factual strand of this movement is Çetin's Anneannem. ${ }^{53}$ After the deportation of the men of her village by the military police in 1915, some of the women take their children and find refuge in a nearby village. Amongst them were 10-year-old Heranush, with her mother Isquhi, brother Horen and sister. The second village met the same fate as the first: the men were killed and the women and children banished and forced on a death march towards the Syrian desert. Heranush survived the march. She was forced out of the caravan and her mother's arms by Hüseyin, a corporal of the military police. He took Heranush into his house, gave her a new name, Seher, and an Islamic upbringing. He treated her well, considered her his daughter, but his wife Esma treated her as a house slave, especially after Hüseyin died young. Horen also survived in this way.

Heranush's mother also survived the death march, eventually reaching Aleppo. After the war, her husband returned from the United States to seek out the family he had left behind years before. He found his wife and together they tried to find their kidnapped children. Working through intermediaries they found both Heranush and Horen. They succeeded in recovering Horen. By this time, Heranush had married and even though at first her husband agreed to visit

${ }^{53}$ My Grandmother was first published in Turkish in November 2004. Geerdink, Fréderike, 'Lawyer and writer Fethiye Çetin: 'My identity has never been purely Turkish', Saturday 20 May 2006, 14-27, http://www.journalistinturkey.com/stories/human-rights/freshair_22/ 
the family in Syria, he changed his mind as he feared losing his wife and children. Heranush remained Seher. Only when she had passed the age of 90 and felt the end of her life approaching, did she confide in her granddaughter. Anneannem was the result, published four years after Heranoush passed away.

The fate of the indigenous Christian Armenian, Hellenic and Assyrian populations of Anatolia and eastern Thrace (modern Turkey) remains a subject of extreme sensitivity within Turkey's borders. This is so not only for the Turkish state, but for large sections of the populace. According to Taner Akçam, the modern Turkish state has a 'very strong moral responsibility in relation to the Armenian, Hellenic and Assyrian genocides'. As he argues in A Shameful Act, there are a number of factors that form a continuity between the three genocides and the foundation of the Republic of Turkey. The political group which organised the genocides was the same party which organised the Turkish movement against the British and French occupation of parts of Anatolia. 'An important number of party members who committed crimes against the Armenians were also very active' in the movement led by Mustafa Kemal Ataturk. ${ }^{54}$ In an interview with the Los Angeles Examiner, 55 Kemal laid responsibility for the Armenian, Hellenic and Assyrian genocides squarely at the feet of the Ittihad's triumvirate of Talaat, Enver and Cemal: 'the former Young Turkey Party, who should have been made [to] account for the lives of our Christian subjects who were ruthlessly driven en masse, from their homes and massacred...'

54 Wilson, Conrad (2006), 'University professor talks about his book on Armenian Genocide', Minnesota Daily, 14 November, http://www.mndaily.com/2009/02/22/university-professor-talksabout-his-book-armenian-genocide 55 Los Angeles Examiner, 1 August 1926, 1. 


\section{Eastern Europe under the Swastika}

The granite wall of the Exhibition Hall of the United States' Holocaust Museum in Washington DC is engraved in block letters with a statement attributed to Adolf Hitler: 'Who after all is today speaking of the destruction of the Armenians?'56 The role of the Armenian, Hellenic and Assyrian genocides as precursors of the Shoah was clearly elaborated by Lemkin and others. A lesser known aspect of the devastation visited upon Poland by the Nazis was their forcible transfer and systematic 'Germanisation' of Christian Polish (and other Baltic) children. By virtue of their faith, Jewish children were destined for the death camps. Losing many relatives in the Shoah, Lemkin was intimately familiar with the developments regarding children and teenagers in his homeland. In Chapter Nine of Axis Rule in Europe, Lemkin discussed the Nazi colonisation of western Poland, a policy to which the forced assimilation of selected Polish children was crucial. ${ }^{57}$

On 25 November 1939, Reichsfuhrer-SS Heinrich Himmler was presented with a special report.58 Given the multinational nature of the existing population, the report pointed out, ' $[t]$ he necessity arises for a ruthless decimation of the Polish population and, as a matter of course, the expulsion of all Jews and persons of Polish-Jewish blood'. In similar ways to the fears of the Ottoman Turks regarding their subject Christian populations, the Nazis were afraid that if left alone the Polish inhabitants of the annexed territories would come

${ }^{56}$ Hitler reportedly made this statement to the summit which began the physical extermination of European Jewry, held at a villa on Wannsee on the outskirts of Berlin on 20 January 1941.

57 Lemkin, 82-83.

58 The report was officially titled 'The issue of treatment of population in former Polish territories from racial-political view'. 
to outnumber the Germans. ${ }^{59}$

Over the following months, special directives were drafted considering the mass forced removal of Polish children that was being prepared. These directives were formulated into one document ${ }^{60}$ on 15 May 1940. In December of that year, Himmler's office ${ }^{61}$ issued a publication stressing the 'essential' nature of this 'chief national task': 'it is an absolute national political necessity to comb out those of German blood in the Incorporated Eastern Territories, and later also in the General Government and to return the lost German blood to its own German people.' ${ }^{\prime 2}$ In the plans for the creation of the Thousand Year Reich, 'Germanisation' of 'racially desirable' people was as important in determining the future of the German nation as military victories against the Allies. As Himmler was once quoted as saying, 'What the nations offer in the way of good blood of our type, we will take, if

59 Trials of War Criminals before the Nuremberg Military Tribunals Under Control Council Law no 10, Nuremberg, October 1946-April 1949 (15 vols, Washington DC, Government Printing Office, 19491953), V, 91 in Lukas, Richard C (2001), Did the Children Cry? Hitler's war against Jewish and Polish children, 1939-1945, New York, Hippocrene Books, http://www.projectinposterum.org/docs/lucas2.htm 60 The report was officially titled Einige Gedanken ueber die Behandlung der Fremdenvoelker im Osten (A few thoughts about treatment of alien people in the East) cited in Milton, Sybil (1997), 'Non-Jewish Children in the Camps', Multimedia Learning Center Online (Annual 5, chapter 2), The Simon Wiesenthal Center, http://motlc.wiesenthal.com/site/pp.asp?c=gvKVLcMVIuG\&b=395 115

${ }^{61}$ Issued in his role as Reichskomissar für die Festigung deutschen Volkstums (Reich Commissioner for the Strengthening of German Folkdom).

${ }^{62}$ Stackelberg, Roderick and Winkle, Sally A (2007), The Nazi Germany Sourcebook: An anthology of texts, New York, Routledge, 271. 
necessary by kidnapping their children and raising them here with us'. ${ }^{63}$ Just as was the case in the Ottoman Empire and Republican Turkey, Nazi ideology regularly took a back seat to practicality when it suited them. The first SS ruler of the Government General, Hans Frank, once stated that,

When we see a blue-eyed child we are surprised that she is speaking Polish...if we were to bring up this child in a German spirit, she will grow up as a beautiful German girl. I admit that in Poland one can find German racial traits among the people and with caring and development will give us Germans in the course of time a possibility to destroy this part of the General Government. ${ }^{64}$

On the orders of SS Gruppenführer Ulrich Greifelt, ${ }^{65}$ six to 12year-olds 'recognised as worthy blood bearers for the Deutschtum' were forcibly transferred to Nazi boarding schools, while younger children would be farmed out to German families by the Lebensborn program. ${ }^{66}$

Himmler delivered a speech on the issue of the forcible transfers of children from eastern Europe at Bad Schahen on 14 October 1943:

I think that it is our duty to take their children with us, to remove them from their environment, if necessary by robbing

63 US Counsel, Nazi Conspiracy and Aggression, IV, 559-60.

64 Pilichowski, Zbrodnie Hitlerowskie, 18, cited in Lukas, Richard C (2001), Did the Children Cry? Hitler's war against Jewish and Polish children, 1939-1945, New York: Hippocrene Books, http://www.projectinposterum.org/docs/lucas3.htm 65 The Chief of the Headquarters of the Reich Commissioner for the Consolidation of German Nationhood.

66 Anordung Nr 67/I, 19 February 1942, Z/Ot,1056, 282V, in AGKBZHP cited in Lukas Richard C (2001), http://www.projectinposterum.org/docs/lucas3.htm 
or stealing them... Either we win over any good blood that we can use for ourselves and give it a place in our people or...we destroy this blood. 6768

Children with suitable 'Aryan' characteristics were arbitrarily removed from orphanages or abducted from parents, grandparents and guardians. Children from unmarried Polish women working as forced labourers in the Reich met the same fate, as did many Polish teenagers who were working as forced labourers. ${ }^{69}$ The members of the Nazi Welfare Organisation (NSV), nicknamed the 'Brown Sisters' (because of their uniforms), played a major role in this systematic forced transfer of children and teenagers. NSV Youth operatives were in action throughout occupied eastern Europe. Using treats such as sweets and bread as lures, the Brown Sisters would seek information on families from unsuspecting children. Armed with this information, the NSV operatives would proceed to the local genealogical records. If the compiled data promised 'racially desirable' results, the child would vanish into the Lebensborn program. ${ }^{70}$

Even the concentration camps were scoured for candidates for 'Germanisation'. Each selected young inmate was placed in quarantine prior to deportation to the Reich. Polish inmate physicians did their utmost to rescue the youngsters by

67 Partial translation of Document L-70 Prosecution Exhibit 384 Extracts from a speech by the Reich Leader SS Himmler at Bad Schchen on 14 October 1943, 989, http://www.mazal.org/archive/nmt/04a/NMT04-T0989.htm ${ }^{68}$ NO-2218, Pros Ex 447.

${ }^{69}$ Hrabar, Hitlerowski Rabunek, 50ff, Wnuk, Dzieci Polskie Oskarzaja, 7-8 cited in Lukas, Richard C (2001), http://www.projectinposterum.org/docs/lucas3.htm ${ }^{70}$ Henry, Clarissa and Hillel, Marc (1975), Children of the SS, translated by Eric Mosbacher, London, Hutchinson and Co, 155-57 cited in Lukas, Richard C (2001), http://www.projectinposterum.org/docs/lucas3.htm 
creative diagnoses of various illnesses. Unlike most of those who went into the Lebensborn program, many of the children who returned from quarantine did not survive the war. ${ }^{71}$

The SS Race and Resettlement Office ${ }^{72}$ established branch offices throughout occupied eastern Europe for the screening and classification of suitably 'Aryan-looking' Poles and others. Classification came in three groups: (a) children with desirable racial characteristics were dispatched to designated centres for further examination; the 'fortunate' ones went on to the homes of Nazi Party loyalists or to Lebensborn ('Well of

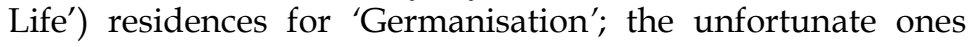
were murdered in Majdanek and Auschwitz; (b) 'racially' less desirable Poles who could contribute economically were sent to the Reich as forced laborers in the Reich; (c) Poles deemed worthless were deported to Auschwitz and almost certain death. ${ }^{73}$

In a number of Kindererziehungslager (child camps) around Poland, preselected children would go through a battery of tests aiming at determining their suitability to 'Germanisation'. Nazi 'racial theoreticians' had developed a checklist of 62 points to assess the candidate's 'racial suitability'. As with most Nazi 'race theory', physical traits were of supreme importance: arms, legs and heads were carefully measured; even the size of a girl's pelvis and a boy's

${ }^{71}$ International Auschwitz Committee, Nazi Medicine, III, 223-24 cite in Lukas, Richard C (2001), http://www.projectinposterum.org/docs/lucas3.htm 72 SS Rasse-und-Siedlungs-Hauptamt (RuSHA).

73 Duraczynski, Wojna i Okupacja [War and Occupation], 393-96 in Lukas, Richard C (2001), http://www.projectinposterum.org/docs/lucas3.htm 
penis were considered important for reproductive purposes. ${ }^{74}$ The object of the tests was not to establish the German descent of the candidate, but rather to assess their physical and mental qualities.

While the process had the veneer of science, it was completely arbitrary, relying heavily on the whim of the medical examiner. For example, 13-year-old Wojciech Wysocki was described as 'Eastern Nordic'. His calm, candid appearance made him 'very promising' for 'Germanisation'. However, if candidates displayed 'negative' character traitsa resistance to 'Germanisation' - they were removed from the program, which usually meant dispatch to a death camp and a cardiac phenol injection. ${ }^{75}$

The Reich authorities were under no delusions that the forcible transfer of Polish and other eastern European children could be justified by any lawful principles. As with much else that they did, they did their utmost to conceal this crime from international and domestic public opinion. The majority of written directives were classified top secret or confidential. In no Nazi document does the term 'Germanisation of Polish children' appear. The most favoured phrase was Wiedereindeutschung ('re-Germanisation').

It has been estimated by Tadeusz Piotrowski that only between 10 and 15 per cent of the Polish children and teenagers forcibly removed returned home after the defeat of the Nazi state. ${ }^{76}$ As one Polish survivor of the process

\footnotetext{
${ }^{74}$ Lukas, Richard C, http://www.projectinposterum.org/docs/lucas3.htm 75 Ibid.

76 Piotrowski, Tadeusz (1998), Poland's Holocaust: Ethnic strife, collaboration with occupying forces and genocide in the Second Republic 1918-1947, 298-99 n73 cited in Paul, Mark 'NEIGHBOURS on the Eve of the Holocaust: Polish-Jewish Relations in Soviet-Occupied Eastern Poland, 1939-1941' Toronto: PEFINA Press 2008, 22,
} 
informed another youngster at a DP camp after the war: 'We used to be Germans. But we are Poles now. In a few weeks you will get to like it too. ${ }^{\prime 77}$

According to official Polish estimates, about 200,000 children and teenagers were forcibly removed by the Nazis. ${ }^{78}$ The Nazis went to great lengths to conceal the origin of the children who ended up in the Lebensborn program and kept few concrete statistics on the abductions. Available figures allow scholars to draw some conclusions about the numbers of forcibly transferred eastern European children and teenagers. ${ }^{79}$ Dr Isabel Heinemann estimated that at least 20,000 Polish children had been kidnapped, as well as a similar number of children from the Soviet Union and a further 10,000 from western and south-eastern Europe, ${ }^{80}$ a total of approximately 50,000 children and teenagers. Dr Susanne Urban, head of historical research at the International Tracing Service in Bad Arolsen in Germany is still dealing with cases of 'Germanisation' and finding the families and origins of victims of those abducted.

In his testimony at one trial at Nuremburg dealing with

http://www.glaukopis.pl/pdf/czytelnia/NeighboursEveOfTheHol ocaust.pdf accessed 13 May 2012.

77 Quotations from Returning Europe's Kidnapped Children, (Exhibit 27), History of Child Welfare, in PAG-4/4.2; Box 81, UN-RRA/UNA as cited in Lukas, Richard C, http://www.projectinposterum.org/docs/lucas3.htm ${ }^{78}$ Moses, A Dirk (ed) (2004), Genocide and Settler Society: Frontier violence and stolen indigenous children in Australian history, New York, Berghahn Books, 260.

79 Gumkowkski, Janusz and Leszczynski, Kazimierz (1961), Poland under Nazi Occupation, Warsaw, Polonia Publishing House cited in http://www.dac.neu.edu/holocaust/Hitlers_Plans.htm

${ }^{80}$ Moses, A Dirk (2004), cited above, 260. 
the mass transfer of non-German children to the Reich, Louis Lavitan $^{81}$ stated that 'a few less than 10,000 children have been located by us, and have either been repatriated or are in stages of repatriation'. Of these, his office had 'complete evidence on exactly 340 as having been in the hands of Lebensborn at one time or another' ${ }^{82}$

\section{Hellenic Civil War}

The transfers of youth during the Hellenic Civil War of 19461949 added a new dimension to this crime. Thousands of youngsters from across mainland Hellas were taken from their homes and sent across the country's northern frontiers in the later stages of this fratricidal conflict. This case was unique until that time as the primary motivation was ideological and the perpetrators were not the dominant group but a minority within the Hellenic state.

Beginning within months of the conclusion of World War II, the civil war was a result of the efforts of the Communist Party of Hellas (KKE) to secure the country for the Soviet bloc in the aftermath of Germany's defeat. The West responded with massive Anglo-American support for the Royal Hellenic Government. Beginning in early 1948, when it was becoming clear that they would be defeated, the Communist guerrillas began systematically removing their young from villages in areas they controlled. Initially, they were sent to the Communist areas along Hellas' northern frontier. From there, they were scattered across the Eastern Bloc, as far as Soviet Central Asia. ${ }^{83}$

${ }^{81}$ Director for the US Zone of the IRO [International Refugee Organisation], Tracing, Child Search Branch.

82 http://www.mazal.org/archive/nmt/04a/NMT04-T0989.htm

83 The General Inspector of the Child Gathering was KKE loyalist Georgios Manoukas. He returned to Hellas in 1961 after denouncing his actions and those of his former party. 
A protest note from the government in Athens stated that more than 7,000 children from 59 rebel-controlled villages had been 'conscripted' and sent over the country's northern borders. ${ }^{84} 85$ With the cessation of hostilities, the Royalist government proclaimed that 29 January 1950 would be marked as a national day of mourning for the removed children. ${ }^{86}$ An investigation by the United Nations' Special Committee on the Balkans (UNSCOB) 'verified the mass deportation of Greek children's7 and found that the total number of persons under 15 years removed behind the Iron Curtain came to $28,296.8889$

This event is perhaps unique in genocide and war crimes history as the primary motivation for the removals was neither for the purpose of religious conversion nor for reasons

84 (AAP) 'Rebels take Children - Greek Protest', Sydney Morning Herald, 5 March 1949, 3.

${ }^{85}$ Citing a rebel radio station broadcast, the London staff correspondent of the Sydney Morning Herald reported on 13 March 1948 that 4,500 children had been removed into Russian satellite countries', 'Greek children seized from parents', Sydney Morning Herald, 13 March 1948, 3.

86 (AAP) 'Greek Day of Mourning', Sydney Morning Herald, 24 December 1949, 3.

87 Report of the United Nations' Special Committee on the Balkans, General Assembly Official Records, Fourth Session Supplement, no 8 (A/935), 21.

88 Diamadis, Panayiotis et al (1995), A Child's Grief: A nation's lament, Sydney, Stentor Press, 33.

89 It estimated that by January 1950 they had been distributed around the Eastern Bloc as follows: Albania $(2,000)$, Czechoslovakia $(2,235)$, Bulgaria $(2,660)$, Hungary and Poland $(3,000$ each), Romania $(3,801)$, and Yugoslavia $(11,600)$. General Assembly Official Record: Fifth Session, Supplement II (A/1307). 
of 'racial purity' - it was openly ideological. The majority of the removed children were not assimilated into other groups but encouraged to retain their Hellenic identities. The victim and the perpetrator groups were members of the same ethnocultural entity; they were all Hellenes, divided solely by politics.

The rhetoric of the Cold War era overshadows much of the literature surrounding the event. For instance, as Karl Rankin claimed:

the [United States'] embassy believes that Markos' abduction of Greek children...is a major psychological blunder which we should exploit by [the] widest possible publication in [the] US and abroad...it can be turned into useful anti-Communist propaganda..$^{90}$

According to the rebels who conducted the mass transfer campaign, the Hellene young were sent to the Eastern Bloc states for humanitarian reasons; to safeguard them from the onslaught of the 'monarcho-fascist' Royal Greek Army. In a radiogram sent on 30 January 1948, the rebel command in northern Hellas demanded that the Belgrade-based KKE Central Committee 'put the question of helping small children, who suffer famine and other misfortunes, in the Free Greek territory'. ${ }^{91}$ In early March 1948, the Communist military leader, Markos Vaphiades, called for the 'evacuation' of 80,000 youths from villages under rebel control in western Macedonia. The Communist authorities in Budapest declared that Hungary welcomed the young Hellenes 'in response to the appeal of the People's Councils of Free Greece'. ${ }^{92}$

90 Wittner, Lawrence (1982), American Intervention in Greece 19431949, New York, Columbia University Press, 162.

${ }^{91}$ Milan, Ristovic (2000), Long Journey Home: The Greek refugees, Thessalonike, Institute for Balkan Studies, 1.

92 Jones, Howard (1989), 'A New Kind of War': America's global strategy and the Truman Doctrine in Greece, New York, Oxford University 
The Hellenic Liaison Service to the United Nations declared that the removed children were destined for 'reeducation', converting the young Hellenes to 'Communist ideology' and ultimately take Hellas into the Soviet bloc. ${ }^{93}$ Although the United Nations Special Commission on the Balkans (UNSCOB) was denied access behind the Iron Curtain, individual Western investigators visited some of the centres hosting removed Hellene children in Bulgaria. They all reported a pattern of ideological indoctrination that matched the accusations of the Royalist government in Athens. ${ }^{94}$

While there was certainly an element of altruism behind the removals, there are a number of effects that support ideology as the ultimate motivating factor. Their education in the Warsaw Pact states was typical of the Communist regimes of that time. In two resolutions (17 November 1948 and 18 November 1949), the United Nations General Assembly called on the governments 'hosting' Hellenic children to return them to their families. ${ }^{95}$ Nor was this the only influential body to

Press, 143.

93 UN General Assembly, Official Records, UNSCOB Report A/574, 3 session, Supplement 8, 1948, 18; Annex 2, 29, 31 in Jones, Howard (1985),'The Diplomacy of Restraint', Journal of Modern Greek Studies, May, 70.

${ }^{94}$ Matthews, Kenneth (1972), Memories of a Mountain War - Greece 1944-1949, London, Longmans, 177, 180-82.

95 Extracts from 'Resolution adopted by the General Assembly of the United Nations' during its Fourth Session. Threats to the political independence and territorial integrity of Greece-288 (IV) (18 November 1949). Noting the report submitted by the International Committee of the Red Cross and the League of the Red Cross Societies on the question of the repatriation of Greek children, and expressing warm appreciation of the efforts made by the two International Red Cross organisations to facilitate the 
make such an appeal. In a letter to his vice-president, Albert Barkley, United States' President Harry Truman stated that his administration 'has exerted and will continue to exert every feasible effort to encourage the repatriation of these children'. The US House of Representatives expressed its support for this outcome in House Resolution 514 of 22 March 1950, ${ }^{96}$ while Senate followed suit with Resolution 212, adopted on 13 September 1950. ${ }^{97}$

According to media reports, the Communist governments had 'agreed to return any children called by petition of their parents'. By the end of 1949, the Hellenic Red Cross had forwarded 8,000 petitions but none of the children had returned. ${ }^{98}$ By 1952, only 684 removed children had been returned to their families; by 1963 , some 4,000 had returned home (including a number of children born in Communist states to children and teenagers who themselves had been removed). The assertion that the motive behind the removals was purely humanitarian is undermined by the exploitation of the removals as a means of psychological warfare against the Hellenic state, refusal to repatriate children as requested by their families and by the rebels' employment of some of

implementation of General Assembly resolution 193 (III) C, noting that the Greek children have not as yet been returned to their homes ... 2. Urges all the Members of the United Nations and other States harbouring the Greek children to make all necessary arrangements, in consultation and co-operation with the international Red Cross organisations, for the early return to their homes of the children with the aforementioned resolution, http://www.un.org/documents/ga/res/4/ares4.htm ${ }^{6}$ Woolley, John T and Peters, Gerhard The American Presidency Project (begun in 1999), Santa Barbara CA, University of California (hosted) Gerhard Peters (database)

http://www.presidency.ucsb.edu/ws/?pid=13766

97 Ibid.

98 'Refugees: Innocents' Day', Time, 9 January 1950, 11. 
the elder teenagers as fighters in the final battles of the civil war.

As noted by one member of the United Nations observation teams, Kenneth Spencer, the key factor in determining the question of how many of the 28,296 Hellenic children were removed voluntarily and how many by force was the status of the parents. As he noted in his article'Greek Children' in The New Statesman and Nation-in prorebel villages parents decided for themselves whether to send their children away; in 'hostile villages', there was 'little doubt that the approach was different and a process of virtual conscription enforced' ${ }^{\prime 9}$ Milan Ristovic estimated that even in anti-government strongholds along the Albanian and Yugoslav frontiers, 'the percentage of the forcibly removed "voluntary refugees" was extremely high, so that in the towns they amounted to up to 29 per cent of the population in 1948$1949^{\prime} .100$

This is an illustration of the methods used by the rebels in 'hostile' villages. Phourka is a mountain settlement nestled next to the Albanian border in the Konitsa district of the Epiros region of north-west Hellas. UNSCOB members recorded Mrs Sophia Makri's statement: when the mothers of the village heard of the rebel plan to 'evacuate' all children under 14 to the Communist countries, they hid their children rather than give them up. When the 21 mothers of the village refused to divulge the location of their children, the women were taken to an isolated spot away from the village and tortured:

99 Spencer, Kenneth (1950), 'Greek Children', The New Statesman and Nation, 39, 31-32.

100 Ristovic, Milan (2000), A Long Journey Home: Greek refugee children in Yugoslavia 1948-1960, Thessaloniki, Institute for Balkan Studies, 1. 
They hung us from pine trees. They burned our feet with coals. They beat us. When we fainted they revived us with cold water from the spring. Fourteen of us died up there but we did not tell. When the Greek army entered our village they found the dead living, for out of the earth came our children. 101

Kallirhoe Gouloumi, from the village of Gorgopotamos, also in Epirus, had a less bloody but no less traumatic story:

They were in our village for a year. First they took our animals, then our food, then our children. I had three. They did not even let me say goodbye. They said they were no longer my children but their children.

Kleoniki Kyprou, from the village of Monopilo in the Kastoria district of western Macedonia, reported: 'First they hanged the priest, then they cut off his mother's hands, and then they ordered us to follow them. What could we do?' In Albania her 8-year-old girl and 5-year-old boy were taken from her and a rifle was thrust into her hands. Tapping the weapon, the rebel kapetanios said: 'This is your husband, this your child'. Kleoniki was forced into the battle of Vitsi. She deserted and got back to her village - without her children. ${ }^{102}$

Many fathers (in some cases both parents) of removed children had migrated abroad before the outbreak of World War II. This was a common phenomenon amongst economic migrants in the inter-war period. The head of the household would migrate then bring out his immediate family as his financial circumstances improved. ${ }^{103}$ Some of the forcibly

101 'Greek Australians seek abducted children', Sydney Morning Herald, 12 January 1950, 2.

102 'Refugees: Innocent's Day', Time, 9 January 1950, 11, http://www.time.com/time/magazine/article/0,9171,811653,00.ht $\mathrm{ml}$

103 The reunion of removed children with their parents in Australia was even raised in the British House of Lords. (Hansard, House of 
removed children and teenagers returned home in the 1950s and 1960s, either in Hellas or in the Diaspora. The majority were not so fortunate. A handful who became involved in activities deemed to be 'anti-Hellenic' by the state remained barred from entering their country of their birth.

The forcible transfer of children from Hellas to the Eastern Bloc states may or may not constitute a case of genocide. There is no evidence that the Communist leadership of the rebel forces responsible for the removals intended to destroy any particular group, in whole or in part. Whether their acts constitute crimes of war depends on the ideological viewpoint of the observer. Given the involvement of the United Nations in these events, it is highly probable that Lemkin and his drafting colleagues were influenced by them in their decision to include such removals as an act of genocide.

\section{Reflections}

How does forcibly transferring children achieve the perpetrator's aim of destroying a targeted group, considering that it does not involve actual killing? What is it that caused the drafter of the Genocide Convention (including Raphael Lemkin) to include these actions as criminal in the legal definition of genocide?

As evidenced by the contents of Lemkin's [until recently] unpublished papers, genocide in colonial contexts

Lords Debate, 28 June 1950, vol 167 cc 1129-31). The children of 24 such families were located in Yugoslavia. ('Greek families will get back lost children', Sydney Morning Herald, 4 May 1950, 11). More removed children were located across six Eastern Bloc states. ('50 Greek children expected to join parents soon', Sydney Morning Herald, 6 May 1950, 5). With the active intervention of the Australian government and the Australian Council for International Social Service, 62 removed children were flown here on specially chartered flights from Belgrade in October and November 1950. 
preoccupied the eminent jurist. On two unpublished pages titled 'Revised Outline for Genocide Cases', Lemkin recorded religious fanaticism, military conquest, political crisis and factors weakening the victim group as 'conditions leading to genocide'. In the same documents, the 'separation of families' is a 'biological method and technique of genocide'; 'forceful conversion' is listed as a 'cultural' method of destruction. ${ }^{104}$

As elaborated here, motivations of perpetrators for child transfer vary. What remains a constant is the intent to destroy family and broader group solidarity by removing members of the next generation of these family and group units. Perpetrators set out to inflict trauma and humiliation by forcibly transferring the most vulnerable members of the group targeted for destruction or disappearance of their ethnicity. In this way, they try to undermine the morale and the ability of that group to resist. By abducting the young and forcibly assimilating them into the dominant group, the targeted minority is denied the opportunity to procreate and therefore to replace themselves. Through the forced impregnation of females from the targeted group, the genocidairés seek to exert a eugenic influence upon the entire population under their control, affecting demographic change to suit their designs.

Ara Sarafian has established that there are four categories of Armenians assimilated by force during the holocaust that engulfed the indigenous Christian peoples of Anatolia. Group A includes those who converted to religion and/or national identity 'voluntarily'. Group B-the individuals who were selected and assimilated by individuals. Group C includes those who were distributed to members and agencies of the dominant group by agencies of the state. Group D enlisted

104 Docker, John (2004), 'Raphael Lemkin's History of Genocide and Colonialism', paper given at the United States' Holocaust Memorial Museum, 26 February, 7-8. 
government-operated orphanages in the forced transfer of children and teenagers. As shown in this essay, these categories apply well beyond the bounds of Sarafian's particular case study. Yet we have to concede that while we assume that the five acts of genocide in the Convention are motivated by malevolence or evil, it is the intent, not the motive, that matters. Nowhere does the Convention indicate that the intent must be of bad faith, and so the 'excuse' of 'good intent' does not arise. In the Australian case, as with the Hellenic children, it matters not that the intent was to be for the children's benefit. What matters is whether they were forcibly removed. They were. 